\title{
Long-term employment outcomes after epilepsy surgery in childhood
}

Jesper Reinholdson, MD, Ingrid Olsson, MD, PhD, Anna Edelvik Tranberg, MD, PhD, * and Kristina Malmgren, MD, PhD*

Neurology ${ }^{\circledR}$ 2020;94:e205-e216. doi:10.1212/WNL.0000000000008681

\author{
Correspondence \\ Dr. Reinholdson \\ jesper.reinholdson@gu.se
}

\section{Abstract}

\section{Objective}

To analyze long-term employment outcomes in a population-based cohort of adults who underwent epilepsy surgery in childhood or adolescence and to compare the results to general population reference data.

\section{Methods}

Prospective data on epilepsy surgery procedures performed on patients $<19$ years of age between 1995 and 2012 were extracted from the Swedish National Epilepsy Surgery Register. Five-, 10-, 15- and 20-year follow-up data were analyzed. Patients aged $\geq 19$ years at follow-up were eligible for inclusion. Educational attainment and employment status were analyzed in relation to seizure outcome. Education and employment outcomes of seizure-free patients with a preoperative IQ of $\geq 70$ were compared to general population reference data.

\section{Results}

A total of 203 patients were included. The mean age at surgery was 13.6 years and $66 \%$ had IQ $\geq 70$. Of these, a majority had attained at least high school education 5 years after surgery. Employment rates were 44\%, 69\%, 71\%, and 77\% at the 5-, 10-, 15-, and 20-year follow-ups, respectively. Seizure-free patients were significantly more likely to work full-time. Educational attainment and rates of full-time employment of seizure-free patients were similar to the general population. A majority of patients with IQ $<70$ had attended special education and were reliant on social benefits.

\section{Conclusion}

Long-term overall employment rates were higher compared to most previous studies on surgery in adults. Seizure-free patients with a preoperative IQ $\geq 70$ showed rates of full-time employment similar to the general population. Further research is needed to determine whether this also applies for occupational complexity and wages.

\footnotetext{
*These authors contributed equally to the supervision of this work.
}

From the Department of Clinical Neuroscience, Institute of Neuroscience and Physiology (J.R., A.E.T., K.M.), and Department of Paediatrics, Institute of Clinical Sciences (I.O.), Sahlgrenska Academy at Gothenburg University, Gothenburg, Sweden. 


\section{Glossary}

CI = confidence intervals; SNESUR = Swedish National Epilepsy Surgery Register; TLR = temporal lobe resection.

For a selected group of children with medically intractable epilepsy, epilepsy surgery is an established treatment option. ${ }^{1}$ The efficacy of epilepsy surgery in achieving seizure freedom or a worthwhile reduction in seizure frequency has been shown in several studies. ${ }^{2,3}$ The goals of epilepsy surgery are not restricted to seizure freedom alone; professional and educational gains in the long term are also desirable, both from the patient/caregiver perspective and for health economic reasons. People with childhood-onset epilepsy show consistently lower educational attainment and rates of employment as adults compared with the general population. ${ }^{4-6}$ There is currently limited knowledge of employment rates after epilepsy surgery in childhood. Studies on the subject intrinsically necessitate long follow-up periods as the participants must have reached an age at which self-sustaining employment is the norm in order for meaningful analyses to be possible. Previous reports have shown a great variance in employment rates $(33 \%-81 \%) .^{7-12}$ The interpretation of previous studies is complicated by short follow-up times and cross-sectional study designs with widely varying follow-up periods. As a consequence, cohorts consist of individuals of varying ages ranging from early adolescence to adulthood.

The aims of this study were to report long-term populationbased educational and employment outcomes in adults who underwent epilepsy surgery in childhood or adolescence, to analyze these findings in relation to postoperative seizure outcome, and to compare the results to general population reference data.

\section{Methods}

This is a population-based observational study based on prospectively collected data from the Swedish National Epilepsy Surgery Register (SNESUR). The SNESUR is a collaboration among all 6 centers performing epilepsy surgery in Sweden (Gothenburg, Lund, Uppsala, Stockholm, Linköping, and Umeå). Preoperative data, information about type of surgery and complications, and 2-year follow-up data have been reported to the register since 1990, including medical and social variables. Long-term follow-ups were initiated in 2005 for patients operated from 1995 onwards. These followups consist of structured telephone interviews conducted every 5th year. As long-term follow-ups began in 2005, patients operated from 1995 to 1999 did not undergo 5-year follow-ups; the first long-term follow-up for those patients was 10 years after surgery. Patients operated in 2000 and later have had follow-ups every 5 years since surgery. The first 20year follow-ups were done in 2015.
All patients who underwent epilepsy surgery in childhood or adolescence ( $<19$ years of age) between 1995 and 2012 and were at least 19 years old at a minimum of one long-term followup $(5,10,15$, or 20 years after surgery) were eligible for inclusion in this study. Some patients in this study have been included in previous articles. ${ }^{13,14}$ In cases of reoperation before 19 years of age, only follow-ups after the last operation were included in the study. Patients reoperated as adults were excluded after the reoperation. These patients are included in an earlier study on vocational outcomes after epilepsy surgery in adults. ${ }^{15}$

Baseline variables studied were sex, age at epilepsy onset, age at surgery, epilepsy duration (between onset and surgery), neurologic deficits, preoperative intellectual functioning dichotomized as IQ $\geq 70$ or $<70$, mean monthly seizure frequency during the year preceding surgery, number of antiepileptic drugs, and type of surgery. Neurologic deficits include motor, visual, speech, and auditory deficits. Intellectual functioning was assessed by means of age-appropriate neuropsychological tests. $^{16}$

The outcome measures were seizure outcome, educational attainment, and employment outcome at each follow-up. Seizure outcome is reported as the mean monthly seizure frequency during the year preceding each follow-up, compared to the seizure frequency reported before surgery. Complete seizure freedom since surgery (without aura) is also reported. As seizure outcome is not the main topic of this study, we chose to pool all patients with persisting seizures into one outcome category. Educational attainment (highest level of education, finished or ongoing) was classified into 4 categories: special education (adapted schooling provided up to the age of 20 for individuals with intellectual disabilities), compulsory school (9 years), high school (3 years following the compulsory 9 years), and postsecondary education (university, college, or vocational education after high school). Employment outcome was categorized into full-time employment, part-time employment, ongoing studies, or reliance on social benefits. Due to the impact of intellectual disability on the ability to work and attain higher education, patients were stratified into 2 groups according to baseline IQ with a cutoff at 70 .

We compared attainment of postsecondary or high school education and rates of full-time employment of seizure-free patients with preoperative IQ $\geq 70$ with general population data. For this purpose, patients were grouped according to age (19-24 or $\geq 25$ years of age at follow-up). Age-matched general population reference data were acquired from Statistics Sweden. General population data on education were collected from the register Educational Attainment of the Population, which is individual-based and encompasses true figures for the 
whole Swedish population. Reference data on employment were acquired from the Labour Force Surveys which, in contrast, are based on samples. Therefore, general population employment figures are estimates with confidence intervals (CIs). Yearly educational attainment and employment data for the period 2005-2017 during which the follow-ups in this study took place were analyzed and mean values for the total period were calculated. Full-time employment was defined as working $\geq 35$ hours per week. The general population reference figures were weighted to match the sex distribution in each of the 4 follow-up cohorts.

\section{Statistical analysis}

For comparisons between 2 groups, Fisher exact test was used for dichotomous variables and the Mann-Whitney $U$ test for ordered categorical variables. For the purpose of comparisons of educational and employment outcomes with general population data, $95 \%$ CIs of patient proportions were derived from the single proportion $Z$ test. Univariate binary logistic regression was performed for the prediction of being employed (full- or part-time). Predictors for employment were sought based on findings in earlier studies. ${ }^{15,17}$ Presented $p$ values are 2-tailed. Missing data were treated as missing at random. Statistical analyses were made in IBM SPSS (Chicago, IL) Statistics 25 for Windows.

\section{Standard protocol approvals, registrations, and patient consents}

The study was approved by the Regional Board of Medical Ethics at the University of Gothenburg. The board considered long-term follow-up after epilepsy surgery to be a quality control measure not necessitating individual consent.

\section{Data availability}

Swedish general population employment and educational data are freely accessible via Statistics Sweden (scb.se/en/). The SNESUR is subject to personal information protection regulations and sharing of anonymized data will be considered on a case-by-case basis on request.

\section{Results}

Between 1995 and 2012, 356 children and adolescents underwent epilepsy surgery in Sweden. A total of 203 patients were included in the study. Seventy-two were followed up 5 years after surgery, 127 after 10 years, 105 after 15 years, and 42 patients 20 years after surgery (figure 1 ).

Baseline characteristics of the included patients are presented in table 1. A majority (61\%) were male and about 1 in 3 patients had a preoperative IQ of $<70$. Temporal lobe resection (TLR) was the most common type of surgery. Nonresective procedures were more prevalent in patients with low $\mathrm{IQ}$, as were neurologic deficits. Differences with respect to baseline variables between included patients and those lost to follow-up were tested for significance (table e-1, doi.org/10.5061/dryad.tf8440h). Except for type of surgery at the 10-year follow-up (more patients undergoing nonresective surgery were lost to follow-up, Fisher exact test: $p=0.007$ ) and sex distribution at the 15 -year followup (more men were lost to follow-up, Fisher exact test: $p=$ 0.031 ), no statistically significant differences were found.

The mean ages at follow-up were 21.7, 24.3, 26.6, and 30.9 years at the 5-, 10-, 15-, and 20-year follow-ups, respectively. A majority of patients with IQ $\geq 70$ in each follow-up cohort were seizure-free: 40/61 (66\%), 58/90 (64\%), 38/61 (62\%), and $14 / 22$ (64\%). In contrast, only 4/11 (36\%), 5/37 (14\%), 8/44 $(18 \%)$, and $3 / 20(15 \%)$ in the IQ $<70$ group were seizure-free at the 5-, 10-, 15-, and 20-year follow-ups, respectively (Fisher exact test: $p=0.095,<0.001,<0.001$, and $=0.002$ ).

\section{Educational outcomes}

Educational outcomes are presented in table 2. In the IQ $\geq 70$ group, a majority had achieved at least high school education 5 years after surgery. The proportion with ongoing or completed postsecondary education increased over time and was higher in seizure-free patients. The differences with respect to seizure outcome were not statistically significant except at the 5-year follow-up (table 2). A majority of the patients with IQ $<70$ had attended special education, as had a lesser proportion of the patients in the IQ $\geq 70$ group.

\section{Educational attainment in the IQ $\geq 70$ group compared to the general population}

Proportions of seizure-free patients with preoperative IQ $\geq 70$ having attained high school or postsecondary education in comparison to general population reference data are presented in figure 2 . Among those aged $\geq 25$ years, $7 / 25$ (28\%, 95\% CI $10 \%-46 \%), 16 / 29$ (55\%, $95 \%$ CI $37 \%-73 \%)$, and $8 / 13$ (62\%, 95\% CI $35 \%-88 \%$ ) had attained postsecondary education at the 10-, 15-, and 20-year follow-ups, respectively. This can be compared with $43 \%, 44 \%$, and $44 \%$ in the general population.

\section{Employment outcomes}

Overall, 27/61 (44\%), 62/90 (69\%), 43/61 (71\%), and 17/22 (77\%) of the patients with IQ $\geq 70$ were employed part-time or full-time compared to 6/11 (55\%), 7/37 (19\%), 11/44 (25\%), and $2 / 20(10 \%)$ in the IQ $<70$ group. The number of students decreased over time. Except at the 5-year follow-up, rates of both full-time employment and any employment (part-time and fulltime combined) were significantly higher for patients with IQ $\geq 70$ than for those with low IQ (Fisher exact test: $p=1.00$, $=0.001,=0.002$, and $<0.001$ at 5-, 10-, 15-, and 20-year follow-ups for full-time employment and $p=0.744,<0.001,<0.001$, and $<0.001$ for any employment). A majority of the patients with IQ $<70$ were reliant on social benefits at all time points except the 5-year follow-up.

Employment outcomes stratified by seizure outcome 5, 10, 15 , and 20 years after surgery are shown in table 3 . In the IQ $\geq 70$ group, 10-, 15-, and 20-year full-time employment rates were significantly higher for seizure-free patients compared to those who still had seizures (table 3). 


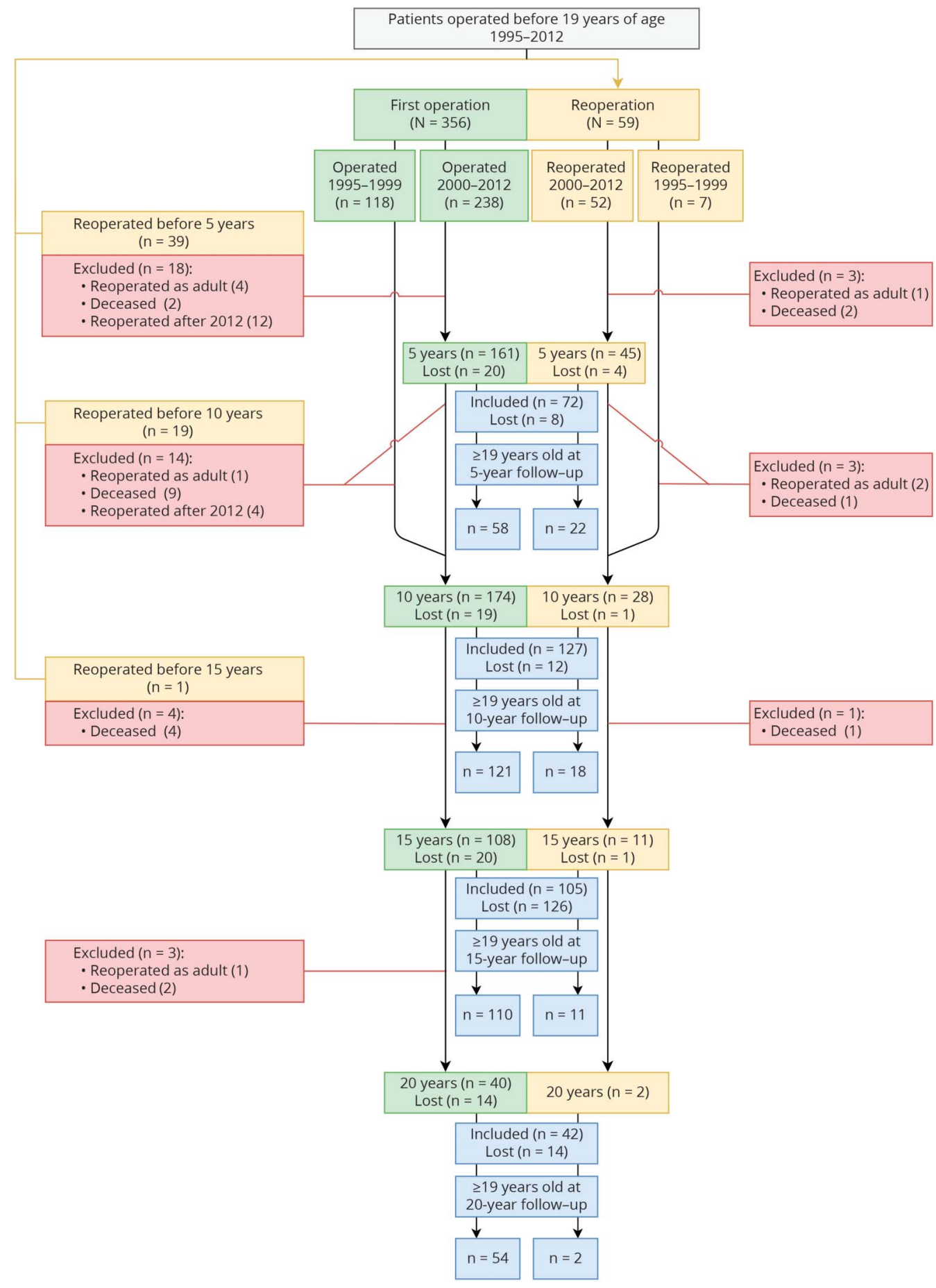

Long-term follow-ups ( $\geq 5$ years after surgery) began in 2005. Therefore, patients operated in 1995-1999 did not undergo a 5-year follow-up and had their first long-term follow-up 10 years after surgery. In cases of reoperation, only outcomes at follow-up after the last operation were included. Only patients aged $\geq 19$ years were included at each follow-up. 5y = 5-year follow-up; 10y = 10-year follow-up; 15y = 15-year follow-up; 20y = 20-year follow-up.

\section{Full-time employment in the IQ $\geq 70$ group compared to the general population}

A comparison between full-time employment rates of patients with IQ $\geq 70$ and general population reference data is shown in figure 3. At the 10-, 15-, and 20-year follow-ups, 17/25 (68\%, $95 \%$ CI 50\%-86\%), 22/29 (76\%, 95\% CI 60\%-91\%), and 8/
13 (62\%, 95\% CI 35\%-88\%) of the seizure-free patients aged $\geq 25$ years worked full-time. In the general population, the corresponding weighted figures were 66\% (95\% CI $65 \%-67 \%$ ), 66\% (95\% CI 65\%-67\%), and 68\% (95\% CI $67 \%-69 \%)$. No patients had reached the age of 25 at the 5 -year follow-up. Of the younger seizure-free patients aged 
Table 1 Baseline characteristics of included patients grouped according to preoperative IQ

\begin{tabular}{|c|c|c|}
\hline & Preoperative IQ $\geq 70$ & Preoperative IQ $<70$ \\
\hline No. & 134 & 69 \\
\hline Sex, male/female (\% male) & $79 / 55(59)$ & $45 / 24(65)$ \\
\hline Age at epilepsy onset, y, mean (SD); median (range) & $7.1(4.6) ; 7.0(0.0-17.4)$ & $1.8(2.1) ; 0.7(0.0-9.0)$ \\
\hline Age at surgery, y, mean (SD); median (range) & $13.6(4.0) ; 14.5(0.2-18.9)$ & $10.6(4.2) ; 10.7(2.5-17.5$ \\
\hline Epilepsy duration, ${ }^{a}$ y, mean (SD); median (range) & $6.5(4.4) ; 6.0(0.1-17.8)$ & $8.8(3.8) ; 8.6(1.6-16.1)$ \\
\hline Monthly seizure frequency at baseline, mean (SD); median (range) & $111(285) ; 20(0.2-2,000)$ & $313(538) ; 100(2-3,300)$ \\
\hline No. of AEDs at baseline, median (range) & $2(1-5)$ & $2(1-4)$ \\
\hline Neurologic deficit, ${ }^{\text {b }}$ (\%) & $23(17)$ & $38(55)$ \\
\hline \multicolumn{3}{|l|}{ Type of surgery, ${ }^{\mathrm{C}} \mathrm{n}(\%)$} \\
\hline TLR & $68(51)$ & $24(35)$ \\
\hline FLR & $28(21)$ & $9(13)$ \\
\hline P/OLR & $19(14)$ & $4(6)$ \\
\hline MLR & $4(3)$ & $4(6)$ \\
\hline HE & $8(6)$ & $7(10)$ \\
\hline CC & $3(2)$ & $16(23)$ \\
\hline $\mathrm{HH}$ & - & $2(3)$ \\
\hline Other & $4(3)$ & $3(4)$ \\
\hline Reoperation, n (\%) & $22(16)$ & $10(15)$ \\
\hline \multicolumn{3}{|c|}{$\begin{array}{l}\text { Abbreviations: } \mathrm{AED}=\text { antiepileptic drug; } C \mathrm{CC}=\text { corpus callosotomy; } \mathrm{FLR}=\text { frontal lobe resection; } \mathrm{HE}=\text { hemispherotomy; } \mathrm{HH}=\text { disconnection of hypothalamic } \\
\text { hamartoma; } \mathrm{MLR}=\text { multilobe resection; Other = stereotactic procedures, multiple subpial transections; } \mathrm{P} / \mathrm{OLR}=\text { parietal or occipital lobe resection; TLR = } \\
\text { temporal lobe resection. } \\
\text { a Time between epilepsy onset and first operation. } \\
\text { b Including motor, visual, speech, and auditory deficits. } \\
\text { c Last operation. }\end{array}$} \\
\hline
\end{tabular}

19-24 years at follow-up, $13 / 40$ (33\%, 95\% CI 18\%-47\%) and $15 / 33$ (45\%, 95\% CI 28\%-62\%) were in full-time employment 5 and 10 years after surgery, whereas the general population full-time employment rates were 39\% (95\% CI $38 \%-40 \%)$ and $38 \%$ (95\% CI 37\%-39\%). Only a few patients were under 25 years of age at the 15- and 20-year follow-ups.

\section{Predictors of employment}

Univariate binary logistic regression analyses of potential predictors of employment (full-time or part-time) are shown in table 4 . Higher age at surgery was associated with greater chances of employment at the 10- and 15-year follow-ups. At the 20-year follow-up, seizure freedom was a positive predictor of employment, whereas $>30$ seizures/mo at baseline was negatively associated with employment at the 15-year follow-up. Due to the small number of significant associations found in the univariate analyses, we chose not to perform further multivariable analyses.

\section{Discussion}

In this prospective, population-based study on long-term employment outcomes after paediatric epilepsy surgery, we found that a majority of patients with a preoperative IQ $\geq 70$ were employed 10 years after epilepsy surgery and that employment rates continued to rise through the 20-year follow-up. At the 5-year follow-up, when the patients were still young adults, the rates of full-time and part-time employment were lower (44\% combined), whereas more patients were students (33\%). Previous studies have yielded widely varying results; employment rates in the literature range from $33 \%$ to $81 \%{ }^{7-12}$ Outcomes with respect to employment and educational attainment are for obvious reasons dependent on the patients' age at follow-up, and thus on the length of follow-up. This is of particular importance in studies of paediatric populations as early adulthood is an age of transition when individuals attain vocational education and enter the labor market. Consequently, cross-sectional studies with mean ages at follow-up in this age span may be difficult to interpret. Three previous studies focusing on outcomes in young adults after surgery in childhood or adolescence have shown that most are either working or engaged in studies, findings that are confirmed by our results. ${ }^{7,10,11}$ Studies with longer follow-up suggest that employment rates increase with higher age at followup; figures ranging from $48 \%$ to $81 \%$ have been reported. ${ }^{8,9,12}$ This pattern is in line with our findings. 
Table 2 Educational attainment in relation to seizure outcome

\begin{tabular}{|c|c|c|c|c|c|}
\hline \multirow[b]{2}{*}{ Seizure outcome } & \multicolumn{4}{|c|}{ Educational attainment, $\mathrm{n}(\%)$} & \multirow[b]{2}{*}{$\begin{array}{l}p \text { Value (postsecondary } \\
\text { education) }^{\mathrm{a}}\end{array}$} \\
\hline & $\begin{array}{l}\text { Postsecondary } \\
\text { education }\end{array}$ & $\begin{array}{l}\text { High } \\
\text { school }\end{array}$ & $\begin{array}{l}\text { Compulsory } \\
\text { school }\end{array}$ & $\begin{array}{l}\text { Special } \\
\text { education }\end{array}$ & \\
\hline \multicolumn{6}{|l|}{ IQ $\geq 70$} \\
\hline \multicolumn{6}{|l|}{ 5-y follow-up, $n=61$} \\
\hline Seizure-free, total $n=40$ & $9(22.5)$ & $23(57.5)$ & $1(2.5)$ & $7(17.5)$ & $0.021^{b}$ \\
\hline Since surgery, $n=28$ & $7(25.0)$ & $16(57.1)$ & $1(3.6)$ & $4(14.3)$ & \\
\hline $\begin{array}{l}\geq 1 \text { y before follow-up, } \\
n=12\end{array}$ & $2(16.7)$ & $7(58.3)$ & 0 & $3(25.0)$ & \\
\hline Seizures, $n=21$ & 0 & $16(76.2)$ & $1(4.8)$ & $4(19.0)$ & \\
\hline \multicolumn{6}{|l|}{$10-y$ follow-up, $n=90$} \\
\hline Seizure-free, total $n=58$ & $18(31.0)$ & $37(63.8)$ & $1(1.7)$ & $2(3.4)$ & 0.072 \\
\hline Since surgery, $n=33$ & $10(30.3)$ & $21(63.6)$ & 0 & $2(6.1)$ & \\
\hline $\begin{array}{l}\geq 1 \text { y before follow-up, } \\
n=25\end{array}$ & $8(32.0)$ & $16(64.0)$ & $1(4.0)$ & 0 & \\
\hline Seizures, $\mathrm{n}=32$ & $4(12.5)$ & $17(53.1)$ & $2(6.3)$ & $9(28.1)$ & \\
\hline \multicolumn{6}{|l|}{$15-\mathrm{y}$ follow-up, $\mathrm{n}=61$} \\
\hline Seizure-free, total $n=38$ & $19(50.0)$ & $15(39.5)$ & 0 & $4(10.5)$ & 0.106 \\
\hline Since surgery, $n=24$ & $15(58.3)$ & $7(29.2)$ & 0 & $3(12.5)$ & \\
\hline $\begin{array}{l}\geq 1 \text { y before follow-up, } \\
n=14\end{array}$ & $5(35.7)$ & $8(57.1)$ & 0 & $1(7.1)$ & \\
\hline Seizures, $n=23$ & $6(26.1)$ & $11(47.8)$ & 0 & $6(26.1)$ & \\
\hline \multicolumn{6}{|l|}{$20-y$ follow-up, $n=22$} \\
\hline Seizure-free, total $n=14$ & $8(57.1)$ & $6(42.9)$ & 0 & 0 & 0.204 \\
\hline Since surgery, $n=8$ & $4(50.0)$ & $4(50.0)$ & 0 & 0 & \\
\hline $\begin{array}{l}\geq 1 \text { y before follow-up, } \\
n=6\end{array}$ & $4(66.7)$ & $2(33.3)$ & 0 & 0 & \\
\hline Seizures, $n=8$ & $2(25.0)$ & $2(25.0)$ & $1(12.5)$ & $3(37.5)$ & \\
\hline \multicolumn{6}{|l|}{ IQ $<70$} \\
\hline \multicolumn{6}{|l|}{ 5-y follow-up, $n=11$} \\
\hline Seizure-free, total $n=4$ & 0 & $1(25.0)$ & 0 & $3(75.0)$ & \\
\hline Since surgery, $n=1$ & 0 & 0 & 0 & $1(100)$ & \\
\hline $\begin{array}{l}\geq 1 \text { y before follow-up, } \\
n=3\end{array}$ & 0 & $1(33.3)$ & 0 & $2(66.7)$ & \\
\hline Seizures, $\mathbf{n}=\mathbf{7}$ & 0 & 0 & $1(14.3)$ & $6(85.7)$ & \\
\hline \multicolumn{6}{|l|}{ 10-y follow-up, $n=37$} \\
\hline Seizure-free, total $n=5$ & 0 & $1(20.0)$ & 0 & $4(80.0)$ & \\
\hline Since surgery, $n=3$ & 0 & 0 & 0 & $3(100)$ & \\
\hline $\begin{array}{l}\geq 1 \text { y before follow-up, } \\
n=2\end{array}$ & 0 & $1(50.0)$ & 0 & $1(50.0)$ & \\
\hline Seizures, $n=32$ & 0 & $1(3.1)$ & $1(3.1)$ & $30(93.8)$ & \\
\hline \multicolumn{6}{|l|}{ 15-y follow-up, $n=44$} \\
\hline Seizure-free, total $n=8$ & 0 & $3(37.5)$ & $1(12.5)$ & $4(50.0)$ & \\
\hline
\end{tabular}


Table 2 Educational attainment in relation to seizure outcome (continued)

\begin{tabular}{|c|c|c|c|c|c|}
\hline \multirow[b]{2}{*}{ Seizure outcome } & \multicolumn{4}{|c|}{ Educational attainment, n (\%) } & \multirow[b]{2}{*}{$\begin{array}{l}p \text { Value (postsecondary } \\
\text { education) }\end{array}$} \\
\hline & $\begin{array}{l}\text { Postsecondary } \\
\text { education }\end{array}$ & $\begin{array}{l}\text { High } \\
\text { school }\end{array}$ & $\begin{array}{l}\text { Compulsory } \\
\text { school }\end{array}$ & $\begin{array}{l}\text { Special } \\
\text { education }\end{array}$ & \\
\hline Since surgery, $n=5$ & 0 & $2(40.0)$ & 0 & $3(60.0)$ & \\
\hline $\begin{array}{l}\geq 1 \text { y before follow-up, } n \\
\quad=3\end{array}$ & 0 & $1(33.3)$ & $1(33.3)$ & $1(33.3)$ & \\
\hline Seizures, $\mathbf{n}=36$ & 0 & $3(8.3)$ & $1(2.8)$ & $32(88.9)$ & \\
\hline \multicolumn{6}{|l|}{ 20-y follow-up, $n=20$} \\
\hline Seizure-free, total $n=3$ & $1(33.3)$ & 0 & 0 & $2(66.7)$ & \\
\hline Since surgery, $\mathrm{n}=\mathbf{2}$ & $1(50.0)$ & 0 & 0 & $1(50.0)$ & \\
\hline $\begin{array}{l}\geq 1 \text { y before follow-up, } n \\
\quad=1\end{array}$ & 0 & 0 & 0 & $1(100)$ & \\
\hline Seizures, n = 17 & 0 & $1(5.9)$ & 0 & $16(94.1)$ & \\
\hline \multicolumn{6}{|c|}{$\begin{array}{l}\text { a } p \text { Values represent results from Fisher exact test comparing attainment of postsecondary education between seizure-free patients (since surgery or during } \\
\text { the year before follow-up) and patients with persisting seizures. } \\
{ }^{\mathrm{b}} p<0.05 \text {. }\end{array}$} \\
\hline
\end{tabular}

It is reasonable to believe that successful surgical intervention in childhood would allow patients to enter adulthood less hindered by their epilepsy, even though associated adverse cognitive, psychiatric, and social factors may still have an influence. As a consequence, pediatric patients could be expected to fare better in terms of long-term employment compared to patients operated later in life who in many cases have had intractable epilepsy all through adolescence and

Figure 2 Educational attainment of seizure-free patients with preoperative IQ $\geq 70$ compared to general population reference data

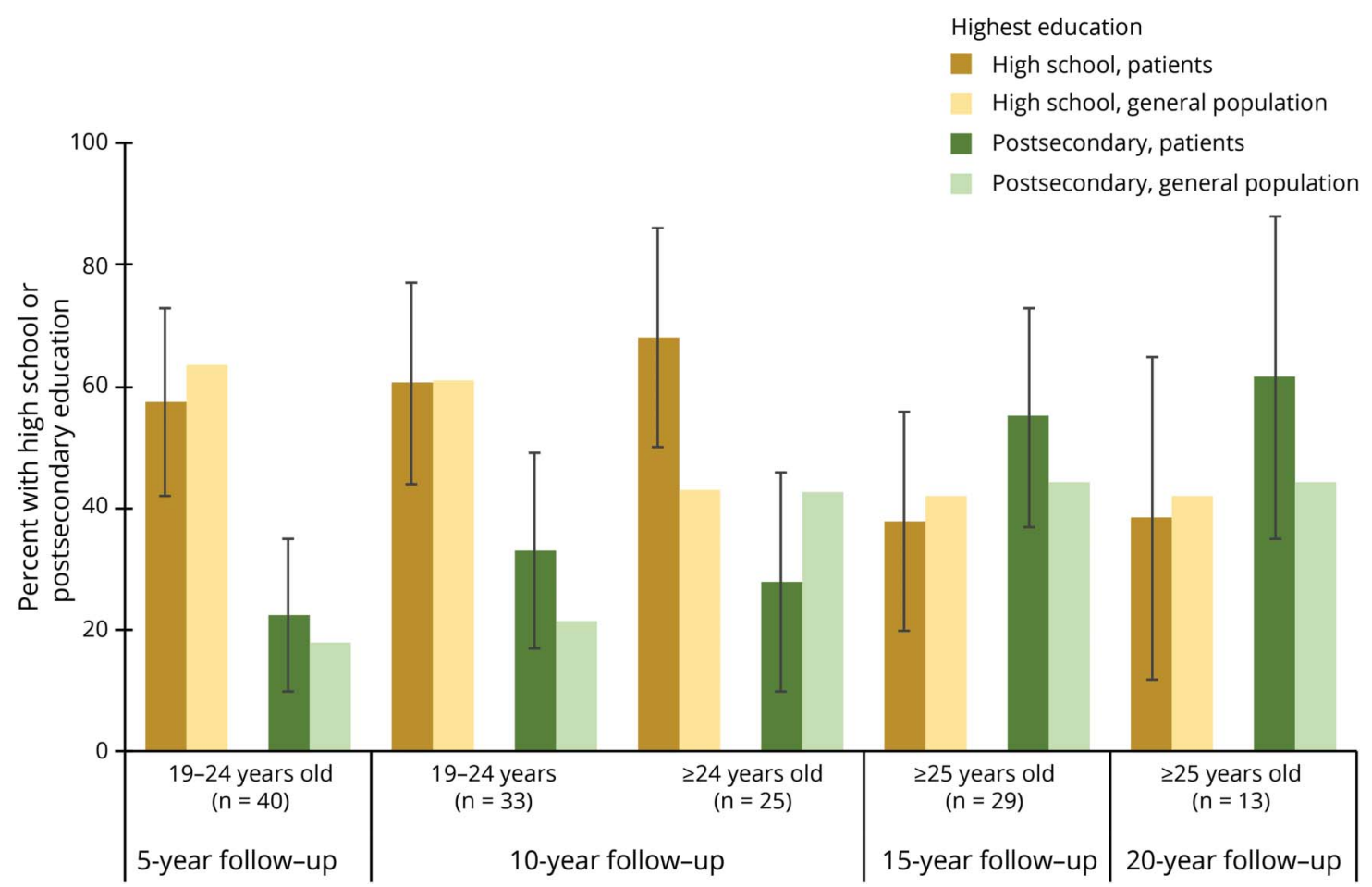

Proportion of seizure-free patients with preoperative IQ $\geq 70$ with high school or postsecondary education at each follow-up compared to corresponding ageand sex-matched general population mean values (2005-2017). Error bars represent 95\% confidence intervals. Numbers in the x-axis labels represent the total number of seizure-free patients with preoperative IQ $\geq 70$ in each age group. 
Table 3 Employment outcome in relation to seizure outcome

\begin{tabular}{|c|c|c|c|c|c|c|}
\hline \multirow[b]{2}{*}{ Seizure outcome } & \multicolumn{4}{|c|}{ Employment outcome, n (\%) } & \multirow{2}{*}{$\begin{array}{l}p \text { Value } \\
\text { (full-time work) }^{a}\end{array}$} & \multirow{2}{*}{$\begin{array}{l}p \text { Value (full-time or } \\
\text { part-time work) }\end{array}$} \\
\hline & Full-time work & Part-time work & Student & On benefits & & \\
\hline \multicolumn{7}{|l|}{$\mathrm{IQ} \geq 70$} \\
\hline \multicolumn{7}{|l|}{ 5-y follow-up, $n=61$} \\
\hline Seizure-free, total $n=\mathbf{4 0}$ & $13(32.5)$ & $7(17.5)$ & $14(35.0)$ & $6(15.0)$ & 0.063 & 0.281 \\
\hline Since surgery, $n=28$ & $8(28.6)$ & $6(21.4)$ & $10(35.7)$ & $4(14.3)$ & & \\
\hline$\geq 1$ y before follow-up, $n=12$ & $5(41.7)$ & $1(8.3)$ & $4(33.3)$ & $2(16.7)$ & & \\
\hline Seizures, $n=21$ & $2(9.5)$ & $5(23.8)$ & $6(28.6)$ & $8(38.1)$ & & \\
\hline \multicolumn{7}{|l|}{ 10-y follow-up, $n=90$} \\
\hline Seizure-free, total $n=58$ & $32(55.2)$ & $11(19.0)$ & $11(19.0)$ & $4(6.9)$ & $0.001^{b}$ & 0.162 \\
\hline Since surgery, $n=33$ & $16(48.5)$ & $10(30.3)$ & $7(21.2)$ & 0 & & \\
\hline$\geq 1$ y before follow-up, $n=25$ & $16(64.0)$ & $1(4.0)$ & $4(16.0)$ & $4(16.0)$ & & \\
\hline Seizures, $\mathrm{n}=32$ & $6(18.8)$ & $13(40.6)$ & $2(6.3)$ & $11(34.4)$ & & \\
\hline \multicolumn{7}{|l|}{ 15-y follow-up, $n=61$} \\
\hline Seizure-free, total $n=38$ & $24(63.2)$ & $6(15.8)$ & $4(10.5)$ & $4(10.5)$ & $<0.001^{\mathrm{b}}$ & 0.085 \\
\hline Since surgery, $n=24$ & $15(62.5)$ & $4(16.7)$ & $3(12.5)$ & $2(8.3)$ & & \\
\hline$\geq 1$ y before follow-up, $n=14$ & $9(64.3)$ & $2(14.3)$ & $1(7.1)$ & $2(14.3)$ & & \\
\hline Seizures, $n=23$ & $2(8.7)$ & $11(47.8)$ & $6(26.1)$ & $4(17.4)$ & & \\
\hline \multicolumn{7}{|l|}{$20-y$ follow-up, $n=22$} \\
\hline Seizure-free, total $n=14$ & $9(64.3)$ & $4(28.6)$ & $1(7.1)$ & 0 & $0.031^{b}$ & $0.039^{b}$ \\
\hline Since surgery, $n=8$ & $6(75.0)$ & $1(12.5)$ & $1(12.5)$ & 0 & & \\
\hline$\geq 1$ y before follow-up, $n=6$ & $3(50.0)$ & $3(50.0)$ & 0 & 0 & & \\
\hline Seizures, $n=8$ & $1(12.5)$ & $3(37.5)$ & $1(12.5)$ & $3(37.5)$ & & \\
\hline \multicolumn{7}{|l|}{ IQ $<70$} \\
\hline \multicolumn{7}{|l|}{$5-y$ follow-up, $n=11$} \\
\hline Seizure-free, total $n=4$ & $1(25.0)$ & $1(25.0)$ & $1(25.0)$ & $1(25.0)$ & & \\
\hline Since surgery, $n=1$ & 0 & 0 & $1(100)$ & 0 & & \\
\hline$\geq 1$ y before follow-up, $n=3$ & $1(33.3)$ & $1(33.3)$ & 0 & $1(33.3)$ & & \\
\hline Seizures, $n=7$ & $2(28.6)$ & $2(28.6)$ & 0 & $3(42.9)$ & & \\
\hline \multicolumn{7}{|l|}{ 10-y follow-up, $n=37$} \\
\hline Seizure-free, total $n=5$ & $1(20.0)$ & $1(20.0)$ & $1(20.0)$ & $2(40.0)$ & & \\
\hline Since surgery, $n=3$ & 0 & $1(33.3)$ & $1(33.3)$ & $1(33.3)$ & & \\
\hline$\geq 1$ y before follow-up, $n=2$ & $1(50.0)$ & 0 & 0 & $1(50.0)$ & & \\
\hline Seizures, $\mathrm{n}=32$ & $3(9.4)$ & $2(6.3)$ & $10(31.3)$ & $17(53.1)$ & & \\
\hline \multicolumn{7}{|l|}{ 15-y follow-up, $n=44$} \\
\hline Seizure-free, total $n=8$ & $3(37.5)$ & $2(25.0)$ & $2(25.0)$ & $1(12.5)$ & & \\
\hline Since surgery, $n=5$ & $3(60.0)$ & 0 & $2(40.0)$ & 0 & & \\
\hline$\geq 1$ y before follow-up, $n=3$ & 0 & $2(66.7)$ & 0 & $1(33.3)$ & & \\
\hline Seizures, $n=36$ & $3(8.3)$ & $3(8.3)$ & $6(16.7)$ & $24(66.7)$ & & \\
\hline
\end{tabular}


Table 3 Employment outcome in relation to seizure outcome (continued)

\begin{tabular}{|c|c|c|c|c|c|c|}
\hline \multirow[b]{2}{*}{ Seizure outcome } & \multicolumn{4}{|c|}{ Employment outcome, n (\%) } & \multirow{2}{*}{$\begin{array}{l}p \text { Value } \\
\text { (full-time work) }^{a}\end{array}$} & \multirow{2}{*}{$\begin{array}{l}p \text { Value (full-time or } \\
\text { part-time work) }^{a}\end{array}$} \\
\hline & Full-time work & Part-time work & Student & On benefits & & \\
\hline \multicolumn{7}{|l|}{$20-y$ follow-up, $n=20$} \\
\hline Seizure-free, total $n=3$ & 0 & $1(33.3)$ & 0 & $2(66.7)$ & & \\
\hline Since surgery, $n=2$ & 0 & $1(50.0)$ & 0 & $1(50.0)$ & & \\
\hline$\geq 1$ y before follow-up, $n=1$ & 0 & 0 & 0 & $1(100)$ & & \\
\hline Seizures, $n=17$ & 0 & $1(5.9)$ & 0 & $16(94.1)$ & & \\
\hline
\end{tabular}

early adulthood. In line with studies of patients operated in childhood, employment outcomes after surgery in adults are disparate. A US multicenter study on resective procedures showed that $55 \%$ of patients were employed after 2 years, ${ }^{18}$ whereas 2 cross-sectional long-term studies with mean followup periods of about 10 years revealed that $70 \%$ were employed following $\mathrm{TLR}^{19}$ and $34 \%$ following all types of resective surgery. ${ }^{20}$ Furthermore, a previous longitudinal study on vocational outcomes after surgery in adults by our group showed a declining trend in employment figures. ${ }^{15}$ Although no firm conclusions should be drawn due to differences in baseline characteristics between adult and pediatric series and markedly higher age at follow-up in studies on adults, it is worth noting that patients with IQ $\geq 70$ in the present study had higher long-term employment rates compared to most previous studies on surgery in adults.

In the current study, rates of full-time employment in the IQ $\geq 70$ group were significantly higher among seizure-free patients at all time points except the 5-year follow-up. In contrast, when full-time and part-time employment were analyzed together, no significant differences with respect to seizure outcome were found except at the 20-year follow-up. An interpretation of this finding could be that active epilepsy in many cases led to a reduction in working hours rather than unemployment. In most previous pediatric studies, small

Figure 3 Full-time employment in seizure-free patients with IQ $\geq 70$ compared to general population reference data

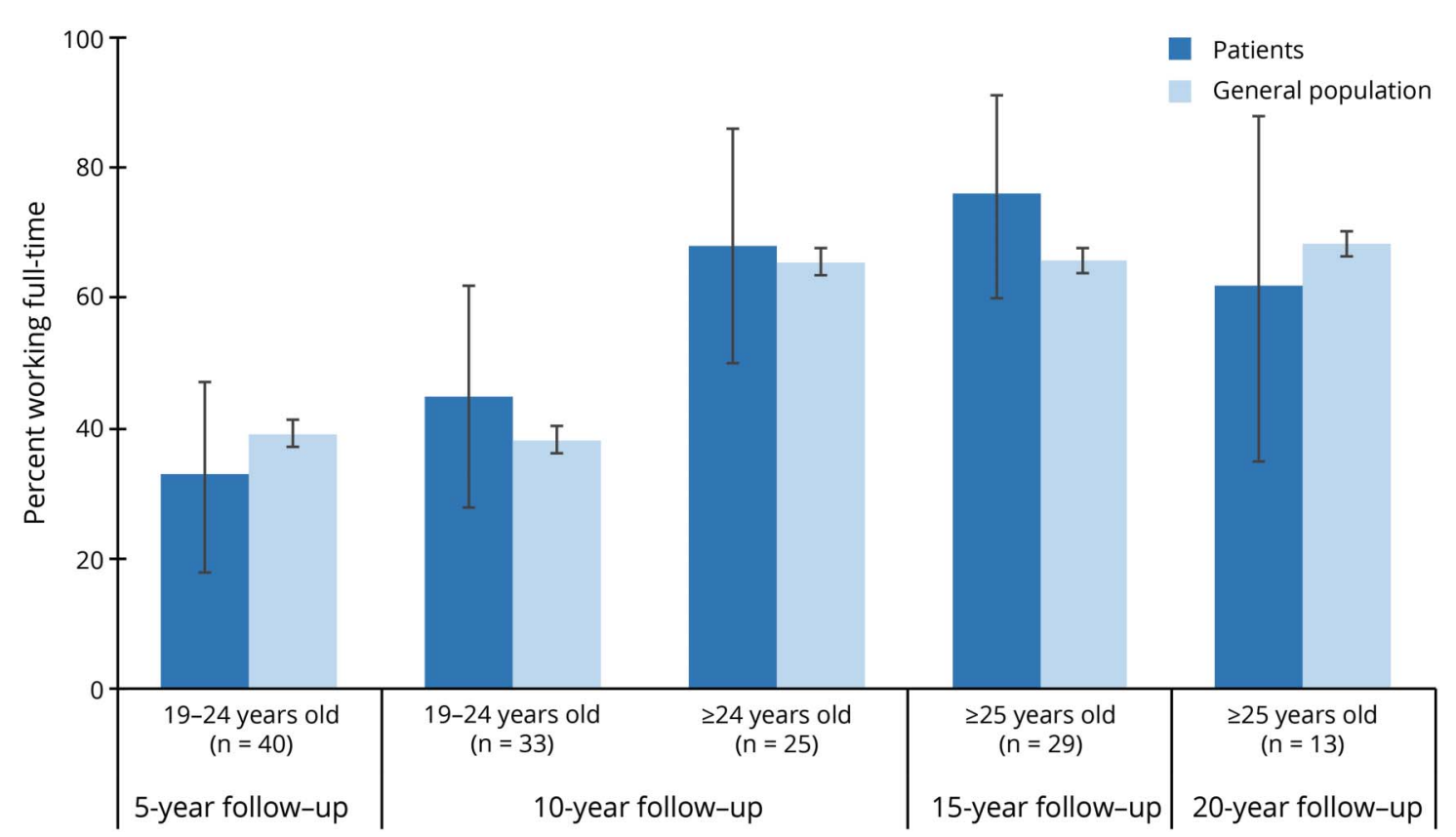

Proportions of seizure-free patients with preoperative IQ $\geq 70$ in full-time employment at each follow-up compared to age- and sex-matched general population mean values (2005-2017). Error bars represent $95 \%$ confidence intervals. Numbers in the $\mathrm{x}$-axis labels represent the total number of seizure-free patients with preoperative IQ $\geq 70$ in each age group. 
Table 4 Univariate logistic regression analyses of predictors for employment (full-time or part-time) in patients with preoperative IQ $>70$

\begin{tabular}{|c|c|c|c|c|c|c|c|c|}
\hline \multirow[b]{3}{*}{ Independent variable } & \multicolumn{8}{|c|}{ Dependent variable } \\
\hline & \multicolumn{2}{|c|}{$\begin{array}{l}\text { Employment at 5-y } \\
\text { follow-up }\end{array}$} & \multicolumn{2}{|c|}{$\begin{array}{l}\text { Employment at 10-y } \\
\text { follow-up }\end{array}$} & \multicolumn{2}{|c|}{$\begin{array}{l}\text { Employment at 15-y } \\
\text { follow-up }\end{array}$} & \multicolumn{2}{|c|}{$\begin{array}{l}\text { Employment at 20-y } \\
\text { follow-up }\end{array}$} \\
\hline & OR (95\% CI) & $\begin{array}{l}p \\
\text { Value }\end{array}$ & OR $(95 \% \mathrm{Cl})$ & $\begin{array}{l}p \\
\text { Value }\end{array}$ & OR $(95 \% \mathrm{CI})$ & $\begin{array}{l}p \\
\text { Value }\end{array}$ & OR $(95 \% \mathrm{CI})$ & $\begin{array}{l}p \\
\text { Value }\end{array}$ \\
\hline Seizure freedom & $\begin{array}{l}2.00 \\
(0.67-6.00)\end{array}$ & 0.216 & $\begin{array}{l}1.96 \\
(0.78-4.91)\end{array}$ & 0.150 & $\begin{array}{l}2.89 \\
(0.93-8.97)\end{array}$ & 0.067 & $\begin{array}{l}13.00 \\
(1.11-152.35)\end{array}$ & $0.041^{a}$ \\
\hline $\begin{array}{l}\text { Preoperative neurologic } \\
\text { impairment }\end{array}$ & $\begin{array}{l}0.35 \\
(0.08-1.439)\end{array}$ & 0.145 & $\begin{array}{l}0.89 \\
(0.24-3.24)\end{array}$ & 0.858 & $\begin{array}{l}0.42 \\
(0.11-1.62)\end{array}$ & 0.208 & $0.09(0.01-1.39)$ & 0.086 \\
\hline Age at surgery & $\begin{array}{l}1.03 \\
(0.85-1.26)\end{array}$ & 0.753 & $\begin{array}{l}1.29 \\
(1.09-1.53)^{a}\end{array}$ & $0.003^{a}$ & $\begin{array}{l}1.24 \\
(1.07-1.44)^{\mathrm{a}}\end{array}$ & $0.005^{a}$ & $1.11(0.91-1.35)$ & 0.297 \\
\hline Relative epilepsy duration & $\begin{array}{l}0.87 \\
(0.12-5.44)\end{array}$ & 0.835 & $\begin{array}{l}0.30 \\
(0.06-1.43)\end{array}$ & 0.129 & $\begin{array}{l}0.28 \\
(0.05-1.76)\end{array}$ & 0.175 & $0.05(0.01-2.30)$ & 0.123 \\
\hline$>30$ Seizures/mo at baseline & $\begin{array}{l}1.20 \\
(0.42-3.42)\end{array}$ & 0.729 & $\begin{array}{l}0.41 \\
(0.16-1.03)\end{array}$ & 0.058 & $\begin{array}{l}0.25 \\
(0.07-0.79)\end{array}$ & $0.018^{a}$ & $0.75(0.10-5.69)$ & 0.781 \\
\hline Sex (ref female) & $\begin{array}{l}2.00 \\
(0.67-6.00)\end{array}$ & 0.216 & $\begin{array}{l}1.39 \\
(0.57-3.39)\end{array}$ & 0.477 & $\begin{array}{l}1.19 \\
(0.40-3.60)\end{array}$ & 0.754 & $1.60(0.20-12.69)$ & 0.656 \\
\hline
\end{tabular}

Abbreviations: $\mathrm{Cl}$ = confidence interval; $\mathrm{OR}=$ odds ratio.

Relative epilepsy duration: epilepsy duration (from onset to surgery) divided by age at surgery.

${ }^{\text {a }} p<0.05$.

cohort sizes, young age at follow-up, and the use of outcome variables combining work and studies have precluded analyses of the association between seizure outcome and employment. ${ }^{9-11,21}$ A significant association between seizure freedom and higher employment rates has been shown in 2 previous studies of epilepsy surgery in childhood ${ }^{7,12}$ as well as in several studies of surgery on adults. $15,17,22$

Comparisons of employment outcomes across countries and time periods are complicated by several factors including economic fluctuations and differences in national social welfare and labor market policies. A means of overcoming these difficulties is to compare results with general population reference data. Seizure-free patients with preoperative IQ $\geq 70$ in our series had rates of full-time employment similar to the general population during the same time period. Although sample sizes were small, this is an encouraging finding. To our knowledge, there is only one previous report on pediatric epilepsy surgery that has included comparisons with general population reference figures; the authors concluded that although there was no difference with respect to a composite measure of employment and school attendance, wages earned were significantly lower. ${ }^{11}$

We found few predictors of employment in this study. Higher age at surgery was associated with greater chances of employment at the 10- and 15-year follow-ups, possibly reflecting the effect of older age at follow-up. Further, seizure freedom was a positive predictor for employment at the 20 -year followup, while $>30$ seizures/mo at baseline was a negative predictor of employment at the 15-year follow-up. To our knowledge, predictors of employment after pediatric epilepsy surgery have not been previously investigated apart from seizure outcome. Studies on surgery in adults have shown preoperative employment status to be a strong predictor of postoperative employment. ${ }^{15,17}$ Although potential effects of the tested clinical variables may have gone unnoticed in the analyses due to small sample sizes, it is probable that factors not available in the register (e.g., school grades and parents' level of education) would have a greater influence on employment outcomes.

Information in the literature about the educational level of adults who had epilepsy surgery in childhood or adolescence is scarce and comparisons between countries are complicated by differences in educational systems. Previous studies have included individuals followed up in early adulthood and show figures of postsecondary education ranging from $23 \%$ to $57 \% .^{7,10,11}$ Only one study from Canada has compared results to general population data and found no significant difference. ${ }^{11}$ In agreement with that study, the proportions of seizure-free patients in our study with a postsecondary education were similar to those of the general population. As discussed above in relation to employment outcomes, the sample sizes were small, and the results should thus be interpreted with caution. In Sweden, all education is tuition-free and low-interest government student loans are available to everyone regardless of parental income. It thus can be argued that these results are difficult to generalize as access to higher education is probably more universal in Sweden than in many other countries. 
About 1 in 3 patients in our cohort had a preoperative IQ of $<70$, a high figure compared to other pediatric series. ${ }^{23,24} \mathrm{In}$ part, the inclusion of nonresective procedures, which are performed more often in patients with intellectual disabilities, explains this difference. As employment prospects for intellectually disabled patients are markedly decreased, ${ }^{25}$ we chose to report outcomes for this group separately. The cutoff at IQ 70 was chosen to align with current criteria for the diagnosis of intellectual disability, which in turn is a prerequisite for admittance to special education in Sweden. ${ }^{26}$ Indeed, a large majority of the patients with IQ $<70$ were shown to have attended special education at follow-up, although a few had completed regular compulsory school or high school and in one case even postsecondary education. With respect to employment outcomes, most relied on social benefits, while a smaller proportion were either students or employed. These outcomes should be interpreted with caution. First, as IQ measurements were made preoperatively and as there is no information about adaptive functioning in the register, it is possible that a few patients in the low IQ group did not meet the diagnostic criteria for intellectual disability at follow-up. Second, special education in Sweden is provided until 20 years of age, after which some individuals take part in further basic vocational training aimed at people with special needs. In part, this explains the finding that a significant proportion of the patients with low IQ were students as adults. Finally, people with permanently reduced working capacity can be entitled to wage subsidies, and it is reasonable to believe that this was the case for some patients in the IQ $<70$ group, although we have no information about this in the register.

The strengths of this study include the prospective, population-based design, which allows us to report results representative for the whole Swedish epilepsy surgery population. As follow-ups took place during a period of more than 10 years, our study is less sensitive to economic fluctuations compared to cross-sectional studies. Moreover, the relatively large cohort size and the long follow-up time made it possible to stratify employment outcomes according to age. This is a major strength of our study since employment outcomes are age-dependent and results from cross-sectional cohorts of patients in the young adult age span might be difficult to interpret. Finally, this is one of few studies of employment outcomes after epilepsy surgery that include comparisons to general population reference data. The design of this study also carries some limitations. First, the register data did not permit analyses of wages, occupational complexity, or the extent of part-time work, and the study also lacks postoperative cognitive assessments. Sample sizes of some subgroups (seizure-free patients with IQ $<70$ and 20-year follow-up data in both IQ groups) were small, and therefore, the results should be interpreted with caution. Furthermore, we did not have follow-up data on all patients at each time point. Finally, the absence of a nonsurgical reference group with intractable epilepsy is a weakness.
A majority of patients with preoperative IQ in the normal range were either employed or studying at long term after pediatric epilepsy surgery. Overall employment rates were higher compared to most previous studies on surgery in adults. Seizure-free patients were significantly more likely to work full-time and showed rates of full-time employment and attainment of postsecondary education similar to the general population. These are encouraging findings that will be of importance in the presurgical counseling process of patients and families. Further research is warranted to evaluate whether outcomes persist into middle age and to analyze occupational distribution and wages.

\section{Acknowledgment}

The authors thank the steering committee of the SNESUR, Sahlgrenska University Hospital, and all regional epilepsy surgery teams (Gothenburg, Lund, Uppsala, Stockholm, Linköping, and Umeå).

\section{Study funding}

Supported by Swedish State Funds for Research at University Hospitals through the LUA/ALF agreement (grant ALFGBG-723151), the Margarethahem Foundation, the Gothenburg Foundation for Neurologic Research, the Linnea and Josef Carlsson Foundation, the Gothenburg Society of Medicine, and the Gothenburg Freemason Lodges.

\section{Disclosure}

The authors report no disclosures relevant to the manuscript. Go to Neurology.org/N for full disclosures.

\section{Publication history}

Received by Neurology February 12, 2019. Accepted in final form July 9, 2019.

\section{Appendix Authors}

\begin{tabular}{|c|c|c|c|}
\hline Name & Location & Role & Contribution \\
\hline $\begin{array}{l}\text { Jesper } \\
\text { Reinholdson, } \\
\text { MD }\end{array}$ & $\begin{array}{l}\text { Gothenburg } \\
\text { University, } \\
\text { Sweden }\end{array}$ & Author & $\begin{array}{l}\text { Study concept and design, } \\
\text { acquisition of data, analysis } \\
\text { and interpretation of the } \\
\text { data, preparation of the initial } \\
\text { manuscript draft }\end{array}$ \\
\hline $\begin{array}{l}\text { Ingrid } \\
\text { Olsson, MD, } \\
\text { PhD }\end{array}$ & $\begin{array}{l}\text { Gothenburg } \\
\text { University, } \\
\text { Sweden }\end{array}$ & Author & $\begin{array}{l}\text { Study concept and design, } \\
\text { analysis and interpretation of } \\
\text { data, critical revision of the } \\
\text { manuscript for intellectual } \\
\text { content, study supervision }\end{array}$ \\
\hline $\begin{array}{l}\text { Anna Edelvik } \\
\text { Tranberg, } \\
\text { MD, PhD }\end{array}$ & $\begin{array}{l}\text { Gothenburg } \\
\text { University, } \\
\text { Sweden }\end{array}$ & Author & $\begin{array}{l}\text { Study concept and design, } \\
\text { acquisition of data, analysis } \\
\text { and interpretation of data, } \\
\text { critical revision of the } \\
\text { manuscript for intellectual } \\
\text { content, study supervision }\end{array}$ \\
\hline $\begin{array}{l}\text { Kristina } \\
\text { Malmgren, } \\
\text { MD, PhD }\end{array}$ & $\begin{array}{l}\text { Gothenburg } \\
\text { University, } \\
\text { Sweden }\end{array}$ & Author & $\begin{array}{l}\text { Study concept and design, } \\
\text { acquisition of data, analysis } \\
\text { and interpretation of data, } \\
\text { critical revision of the } \\
\text { manuscript for intellectual } \\
\text { content, study supervision }\end{array}$ \\
\hline
\end{tabular}




\section{References}

1. Cross JH, Jayakar P, Nordli D, et al. Proposed criteria for referral and evaluation of children for epilepsy surgery: recommendations of the subcommission for pediatric epilepsy surgery. Epilepsia 2006;47:952-959.

2. Dwivedi R, Ramanujam B, Chandra PS, et al. Surgery for drug-resistant epilepsy in children. N Engl J Med 2017;377:1639-1647.

3. Spencer S, Huh L. Outcomes of epilepsy surgery in adults and children. Lancet Neurol 2008;7:525-537.

4. Sillanpaa M, Jalava M, Kaleva O, Shinnar S. Long-term prognosis of seizures with onset in childhood. N Engl J Med 1998;338:1715-1722.

5. Jennum P, Christensen J, Ibsen R, Kjellberg J. Long-term socioeconomic consequences and health care costs of childhood and adolescent-onset epilepsy. Epilepsia 2016;57:1078-1085.

6. Camfield C, Camfield P, Smith B, Gordon K, Dooley J. Biologic factors as predictors of social outcome of epilepsy in intellectually normal children: a population-based study. J Pediatr 1993;122:869-873.

7. Keene DL, Loy-English I, Ventureyra EC. Long-term socioeconomic outcome following surgical intervention in the treatment of refractory epilepsy in childhood and adolescence. Childs Nerv Syst 1998;14:362-365.

8. Benifla M, Rutka JT, Otsubo H, et al. Long-term seizure and social outcomes following temporal lobe surgery for intractable epilepsy during childhood. Epilepsy Res 2008;82:133-138.

9. Jarrar RG, Buchhalter JR, Meyer FB, Sharbrough FW, Laws E. Long-term follow-up of temporal lobectomy in children. Neurology 2002;59:1635-1637.

10. Lach LM, Elliott I, Giecko T, et al. Patient-reported outcome of pediatric epilepsy surgery: social inclusion or exclusion as young adults? Epilepsia 2010;51:2089-2097.

11. Puka K, Smith ML. Where are they now? Psychosocial, educational, and vocational outcomes after epilepsy surgery in childhood. Epilepsia 2016;57:574-581.

12. Hosoyama H, Matsuda K, Mihara T, et al. Long-term outcomes of epilepsy surgery in 85 pediatric patients followed up for over 10 years: a retrospective survey. J Neurosurg Pediatr 2017;19:606-615.
13. Edelvik A, Rydenhag B, Olsson I, et al. Long-term outcomes of epilepsy surgery in Sweden: a national prospective and longitudinal study. Neurology 2013;81:1244-1251. 14. Reinholdson J, Olsson I, Edelvik A, et al. Long-term follow-up after epilepsy surgery in infancy and early childhood: a prospective population based observational study. Seizure 2015;30:83-89.

15. Edelvik A, Flink R, Malmgren K. Prospective and longitudinal long-term employment outcomes after resective epilepsy surgery. Neurology 2015;85:1482-1490.

16. Malmgren K, Olsson I, Engman E, Flink R, Rydenhag B. Seizure outcome after resective epilepsy surgery in patients with low IQ. Brain 2008;131:535-542.

17. Reeves AL, So EL, Evans RW, et al. Factors associated with work outcome after anterior temporal lobectomy for intractable epilepsy. Epilepsia 1997;38:689-695.

18. Chin PS, Berg AT, Spencer SS, et al. Employment outcomes following resective epilepsy surgery. Epilepsia 2007;48:2253-2257.

19. Zarroli K, Tracy JI, Nei M, Sharan A, Sperling MR. Employment after anterior temporal lobectomy. Epilepsia 2011;52:925-931.

20. Wasade VS, Elisevich K, Tahir R, et al. Long-term seizure and psychosocial outcomes after resective surgery for intractable epilepsy. Epilepsy Behav 2015;43:122-127.

21. Engelhart MC, van Schooneveld MM, Jennekens-Schinkel A, van Nieuwenhuizen O With the benefit of hindsight: would you opt again for epilepsy surgery performed in childhood? Eur J Paediatr Neurol 2013;17:462-470.

22. Lendt M, Helmstaedter C, Elger CE. Pre- and postoperative socioeconomic development of 151 patients with focal epilepsies. Epilepsia 1997;38:1330-1337.

23. Gleissner U, Clusmann H, Sassen R, Elger CE, Helmstaedter C. Postsurgical outcome in pediatric patients with epilepsy: a comparison of patients with intellectual disabilities, subaverage intelligence, and average-range intelligence. Epilepsia 2006;47:406-414.

24. Vasconcellos E, Wyllie E, Sullivan S, et al. Mental retardation in pediatric candidates for epilepsy surgery: the role of early seizure onset. Epilepsia 2001;42:268-274.

25. Bush KL, Tasse MJ. Employment and choice-making for adults with intellectual disability, autism, and down syndrome. Res Dev Disabil 2017;65:23-34.

26. Neurodevelopmental disorders. In: Diagnostic and Statistical Manual of Mental Disorders, 5th ed. Washington, DC: American Psychiatric Association; 2013. 